\title{
ТРІЩИНОСТІЙКІСТЬ ЦЕНТРАЛЬНО РОЗТЯГНУТИХ КОМБІНОВАНО АРМОВАНИХ ЗАЛІЗОБЕТОННИХ ЕЛЕМЕНТІВ
}

\section{CRACK RESISTANCE OF CENTRALLY STRETCHED COMBINED RE-ENFORCED REINFORCED CONCRETE ELEMENTS}

Андрійчук О. В., к.т.н., доц. (Луцький національний технічний університет), Бабич В. С., к.т.н., доцент, Поляновська О. С., к.т.н., Швець І. В., аспірант (Національний університет водного господарства та природокористування)

Andriichuk O. V., Candidate of Technical Sciences, Associate Professor (Lutsk National Technical University), Babych V. Ye., Candidate of Technical Sciences, Associate Professor, Polianovska O. Ye., Candidate of Technical Sciences, Shvets I. V., graduate student (National University of Water and Environmental Engineering)

Наведена методика визначення основних параметрів дисперсного об'ємного армування в сполученні з поздовжньою стержньовою арматурою для центрально розтягнених залізобетонних елементів, в яких в процесі експлуатації утворення трішин не допускається. В основу методики покладена математична модель визначення зусилля трішиноутворення, яка базується на основі математично планованого експерименту з варіюванням міцності бетону, довжини сталевої фібри та коефіцієнту об'ємного дисперсного армування. Методика реалізована на прикладі стіни ичліндричного резервуара для води.

Reinforced concrete structures, in which during normal operation the sudden appearance of cracks is not allowed occur in the practice of erection of buildings and structures in many cases

Such constructions, as a rule, are executed with prestressing of working rod armature that leads to additional power expenses. In the practice of construction, combined reinforced concrete structures are beginning to be used, in which rod work reinforcement and volume dispersed reinforcement with steel fiber are used at the same time. In such structures, the resistance to tensile forces from external loads increases significantly, but the use of such structures is limited due to the lack of methods for their calculation and determination of rational parameters of disperse reinforcement.

The article presents a method for determining the parameters of volume dispersion reinforcement with steel fiber of a centrally stretched reinforced concrete element on the example of calculating the wall of a cylindrical tank, in which during normal operation the formation of cracks is not allowed.

The method is grounded on a mathematically planned experiment, based on which a mathematical model was obtained to determine the strength of reinforced concrete and crack force in the wall depending on the main factors of influence: concrete strength, length of steel fiber and volume dispersion reinforcement. For a cylindrical tank for 
liquid with a diameter of $18 \mathrm{~m}$ and a height of $4.8 \mathrm{~m}$ based on the analysis of the obtained mathematical model of wall resistance to cracking and taking into account the expense of fiber per 1 cubic meter of concrete, the rational parameters of its volumetric disperse reinforcement are: when using concrete class C30 / 35 fiber length $60 \mathrm{~mm}$ with a expense of $50 \mathrm{~kg}$ per cubic meter of concrete; when using concrete class C32 / 40 fiber length $50 \mathrm{~mm}$ with a expense of $39 \mathrm{~kg}$ per cubic meter of concrete.

The final choice of the parameters of dispersed reinforcement from the above two must be determined by cost, based on the actual conditions of construction of the tank

Ключові слова: центрально розтягнуті елементи, комбіноване армування, тріщиностійкість, фактори впливу, математично планований експеримент, математична модель тріщиностійкості.

Keywords: centrally stretched elements, combined reinforcement, crack resistance, influencing factors, mathematically planned experiment, mathematical model of crack resistance.

Постановка задачі дослідження. Численні залізобетонні конструкції та їх елементи в процесі експлуатації сприймають розтягуючі зусилля, до таких елементів можна віднести нижні пояси ферм, затяжки арок, стіни циліндричних резервуарів та силосів, опорні кільця куполів, висячі оболонки та інші. До таких залізобетонних конструкцій, залежно від умов експлуатації та їхніх особливостей, ставиться низка вимог, серед основних 3 яких вимога відсутності в них тріщин у процесі експлуатації. Вимоги відсутності тріщин ставлять до залізобетонних конструкцій, в яких для повністю розтягнутого перерізу повинна бути забезпечена непроникність, до унікальних конструкцій із підвищеними вимогами за довговічністю, а також до конструкцій, що експлуатуються в умовах агресивного середовища [1].

Для забезпечення необхідної тріщиностійкості конструкцій наразі застосовують певні заходи, до яких можна віднести влаштування попереднього напружування арматури, використання бетону високої міцності, що тягне за собою додаткові матеріальні та енергетичні витрати. В останній час для підвищення опору залізобетонних елементів утворенню тріщин розглядається їх комбіноване армування, тобто, сполучення армування стрижневою поздовжньою арматурою з фібровим дисперсним армуванням бетону, для якого рекомендується сталева фібра.

В роботах $[2,3,4]$ доведена доцільність використання комбінованого армування в згинальних і центрально розтягнутих елементах, які мають прямокутний переріз з відношенням меншої сторони до більшої в межах 0,4 - 0,8. Відомо, що міцність дисперсно армованого бетону залежить від відношення меншого і більшого розмірів поперечного перерізу елемента до довжини фібри, що враховується коефіцієнтом орієнтації фібри [6]. В наведених роботах такі відношення змінювалися в межах $3,3-12,5$. В практиці будівництва зустрічаються елементи, в яких такі відношення 
можуть змінюватися в інтервалі 1 - 25 (стіни резервуарів, силосних корпусів тощо). Але дослідження для таких елементів не виконувалися.

3 огляду на наведене, в статті ставиться задача дослідити тріщиностійкість комбіновано армованої стіни резервуара для води та розробити методику визначення його оптимальних параметрів.

Огляд попередніх досліджень. В роботі [3] досліджено вплив дисперсного армування в розтягнутій зоні залізобетонних балок на їхню тріщиностійкість. Розроблена розрахункова схема напруженодеформованого стану поперечного перерізу залізобетонної балки з шаром бетону 3 дисперсним армуванням у розтягнутій зоні перед утворенням тріщин, на основі якої отримані формули для визначення моменту тріщиноутворення. В основу використаної деформаційної методики визначення моменту тріщиноутворення покладена повна діаграма деформування бетону і сталефібробетону, яка описується поліномом п'ятого ступеня [1].

3 наведених формул випливає, що опір комбіновано армованих балок тріщиноутворенню залежить від міцності сталефібробетону, яка визначається за формулами [6] і на яку впливає низка факторів, серед яких: клас бетону; довжина і діаметр фібри; процент об'ємного дисперсного армування; процент поздовжнього армування стержневою арматурою; розміри розтягнутого поперечного перерізу або його частини.

Щоб визначити оптимальні параметри дисперсного армування, необхідно знати вплив на міцність сталефібробетону при розтяганні значень кожного фактору та їх сполучень. Математично вирішити цю задачу при названій кількості факторів практично неможливо, а тому автори роботи [3] для аналізу вибрали, на їх погляд, найбільш впливові змінні фактори, а саме: об'ємний процент вмісту фібри $\boldsymbol{\mu}_{f v}$, процент поздовжньої арматури $\boldsymbol{\mu}_{\boldsymbol{s}}$, товщина шару фібробетону $\boldsymbol{c}_{\boldsymbol{f}}$. Інші фактори прийняті фіксованими.

Оскільки міцність сталефібробетону на розтяг залежить від відношення розмірів поперечного перерізу до довжини фібри, в роботі [3] для дослідження прийнята балка розміром $\boldsymbol{b} \times \boldsymbol{h}=25 \times 60 \mathrm{~cm}$, яка виготовляється 3 бетону класу С25/30 і армується поздовжніми стержнями класу А500С. Для визначення впливу вибраних факторів на міцність сталефібробетону при розтяганні та момент тріщиноутворення виконано числовий експеримент із його математичним плануванням, на основі плану Бокса-Бенкіна. В експерименті варіювалися фактори в межах: $\boldsymbol{\mu}_{f v}=0,2-1,8 \% ; \boldsymbol{\mu}_{s}=0,5-1,5 \% ; \boldsymbol{c}_{f} / \boldsymbol{h}=0,05-0,25$.

За результатами числового математично планованого експерименту отримана математична модель для визначення моменту тріщиноутворення в нормальних перерізах балки залежно від розглянутих факторів та їх взаємодії. Середнє відношення теоретичних значень моменту тріщиноутворення, знайдених за отриманою математичною моделлю, до 
значень, отриманих в числовому експерименті, склало 1,13 при мінливості 7,7\%. Це свідчить про те, що математична модель адекватно описує результати числового планованого експерименту.

На підставі аналізу отриманої математичної моделі для визначення моменту тріщиноутворення балок із їх частковим дисперсним армуванням розтягнутої зони автори роботи [3] дійшли висновків, що дисперсне армування шару бетону в розтягнутій зоні балок змінює напруженодеформований стан їх поперечного перерізу та сприяє суттєвому збільшенню моменту тріщиноутворення (в два і більше разів). Крім цього рекомендується процент об'ємного дисперсного армування приймати в межах $\boldsymbol{\mu}_{f v}=1-1,8 \%$, а товщину шару дисперсного армування рівною подвійній віддалі від нижньої грані балки до центра ваги розтягнутої арматури.

Для центрально розтягнутих залізобетонних елементів в роботі [5] запропоновано метод визначення оптимального дисперсного армування, який полягає в побудові математичної моделі визначення їхньої тріщиностійкості залежно від таких основних факторів впливу: міцності бетону, розмірів фібри, коефіцієнта об'ємного армування. Для побудови математичної моделі тріщиностійкості використані результати математично планованого експерименту для комбіновано армованого нижнього поясу ферми прольотом 24 м, який має прямокутний переріз $b \times h$ $=25 \times 30$ см. Реалізований план Бокса-Бенкіна, в якому варіювання прийнятих факторів впливу знаходяться в межах: характеристичне значення призмової міцності бетону $f_{c k}=18,5-25,5$ МПа; довжина сталевої хвилеподібної фібри $l_{f}=40-60$ мм; коефіцієнт об'ємного дисперсного армування $\mu_{\mathrm{fv}}=0,4-1,8 \%$. Отримані математичні моделі тріщиностійкості дали можливість визначити оптимальні параметри дисперсного армування, якому відповідає сталева хвилеподібна фібра довжиною 50 мм в об'ємі 1,8\%. Це дозволяє збільшити зусилля тріщиноутворення на $80 \%$ i уникнути попереднього напружування поздовжньої арматури.

Побудова математичної моделі тріщиностійкості стіни резервуара для води. Для побудови математичної моделі тріщиностійкості вибрана стіна циліндричного резервуара для води з уніфікованим параметрами: діаметр резервуара - 18 м; висота $-4,8$ м; товщина стіни - 0,16 м. Виникнення тріщин в стіні резервуара не допускається.

Для забезпечення міцності i тріщиностійкості циліндричного резервуара використовується комбіноване армування без попереднього напружування кільцевої стержньової арматури. Розглядається частина поперечного перерізу стіни висотою $h=100$ см в нижній частині резервуара. За статичним розрахунком в центрі ваги поперечного перерізу, що розглядається, діють центрально розтягуючі сили 3 розрахунковим 
граничним значенням $N_{E d}=510$ кН та сила від характеристичного навантаження $-N_{E k}=480 \kappa \mathrm{H}$.

За розрахунком за міцністю кільцева стержньова арматура в стіні резервуара прийнята в кількості $10012 \mathrm{A500C}\left(A_{s}=11,31 \mathrm{~cm}^{2}\right)$. Стержні розташовані біля внутрішньої і зовнішньої поверхонь стіни 3 кроком у вертикальному напрямку, рівним 20 см. Захисний шар бетону прийнятий рівним 20 мм.

Визначення оптимальних параметрів дисперсного армування здійснюється за допомогою математичних моделей (рівнянь математичної регресії), які отримуються за допомогою виконання математично планованого експерименту [5].

В числовому експерименті за основні фактори впливу на тріщиностійкість сталефібробетону прийняті: $x_{1}-$ клас бетону (характеристичне значення призмової міцності бетону, $f_{c k}$ ); $x_{2}$ - довжина сталевої фібри, $\left.l_{f}\right) ; x_{3}$ - коефіцієнт об'ємного дисперсного армування, $\left.\mu_{f v}\right)$. Розміри сталевої хвилеподібної фібри прийняті відповідно до ТУ У В.2.7-28.7-00191046-015:2007. Для зведення стін резервуара використовується дрібнозернистий бетон. Умови планування числового експерименту наведені в табл. 1.

Таблиця 1

Умови планування числового експерименту

\begin{tabular}{|c|c|c|c|c|c|}
\hline \multicolumn{2}{|c|}{ Фактори, вигляд } & \multicolumn{3}{|c|}{ Рівні варіювання } & \multirow{2}{*}{$\begin{array}{c}\text { Інтервал } \\
\text { варіювання }\end{array}$} \\
\hline натуральний & кодований & -1 & 0 & +1 & \\
\hline $\mathrm{f}_{\mathrm{ck}}, \mathrm{M \Pi а}$ & $\mathrm{x}_{1}$ & 22,0 & 25,5 & 29,0 & 3,5 \\
\hline $\mathrm{l}_{\mathrm{f}}, \mathrm{MM}$ & $\mathrm{X}_{2}$ & 40 & 50 & 60 & 10 \\
\hline$\mu_{\mathrm{fv}}$ & $\mathrm{x}_{3}$ & 0,002 & 0,010 & 0,018 & 0,008 \\
\hline
\end{tabular}

Для визначення зусилля опору розрахункового перерізу стіни резервуара розтягу необхідно знати характеристичні значення опору розтягу безпосередньо сталефібробетону, які визначаються за формулами [6]. При цьому вид формули залежить від характеру руйнування сталефібробетону при розтяганні, яке в свою чергу залежить від довжини анкерування фібри в бетоні, що забезпечує іiі розрив при висмикуванні $l_{f b}$. Значення $l_{f b}$ визначається за формулою [6]

$$
l_{f b}=\frac{p_{j} d_{j f j k}}{f_{c k}},
$$

де $d_{f}$ - діаметр фібри $\left(d_{f}=1 \mathrm{Mм}\right)$;

$\eta_{f}-$ коефіцієнт, що враховує вид фібр (для хвилеподібної фібри $\left.\eta_{f}=0,85\right)$;

$f_{f k}-$ характеристичне значення опору фібри розтягу (для сталевої фібри мінімальне значення приймається $f_{f k}=800 \mathrm{MПа} \mathrm{[6]).}$ 
При $l_{f b}<0,5 l_{f}$ опір розтягу сталефібробетону вичерпується через розрив деякої кількості фібр і висмикування інших і визначається за формулою [6]

$$
f_{c f t k}=1,1\left[K_{T} h_{o r}^{2} \mu_{f v} f_{f k}\left(1-l_{f b} / l_{f}\right)+0,1 f_{c k}\left(0,8-\sqrt{2 \mu_{f V}-0,005}\right)\right] \text {, }
$$

а при $l_{f b} \geq 0,5 l_{f}$ опір розтягу сталефібробетону вичерпується через висмикування із бетону умовно всіх фібр і визначається за формулою

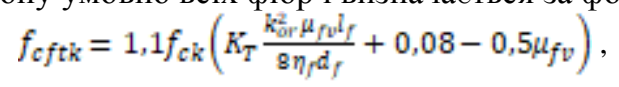

де $f_{c k}$ - характеристичне значення призмової міцності бетону;

$f_{f k}$ - характеристичне значення фібри розтягу (для сталевої фібри мінімальне значення приймається $f_{f k}=800 \mathrm{MПа} \mathrm{[6]).}$

$K_{T}-$ коефіцієнт, який залежить від коефіцієнта $\mu_{f v}$, заходиться за формулою [6]

$$
K_{T}=\sqrt{1-\left(1,2-80 \mu_{f D}\right)^{2}},
$$

$k_{o r}-$ коефіцієнт, який враховує орієнтацію фібр в об'ємі бетону залежно від співвідношення розмірів поперечного перерізу елемента до довжини фібри, приймається по таблиці [6].

Коефіцієнт $K_{T}$ за формулою (4) для значень $\mu_{f v}=0,002 ; 0,010$ і 0,0018 прийнятий відповідно рівним $K_{T}=1,0 ; 0,92$ та 0,97. Відношення більшої сторони перерізу до довжини фібр 40, 50, і 60 мм відповідно рівні 25, 29 та 16,7 , а меншої сторони - відповідно 4,0; 3,2 та 2.7. За таких значень відношень за таблицею 6.1 [6] прийняті значення коефіцієнтів $k_{o r}$, які використані в формулах (2) і (3).

Значення відношення $l_{f b} / l_{f}$ менше 0,5 тільки для бетону класу C30/35 при довжині фібри 60 мм і для класу бетону С32/40 при довжині фібр 50 i 60 мм. В цих випадках значення опору сталефібробетону розтягу визначалися за формулою (2), в інших випадках - за формулою (3). Знайдені значення $f_{c f k}$ наведені в табл. 2, аналіз якої свідчить, що дисперсне армування може збільшити опір бетону розтягу може бути збільшений на 11 - 162\%. Найбільше збільшення міцності сталефібробетону на розтяг спостерігається при використанні фібри довжиною 60 мм. В цьому випадку найбільша вірогідність розташування фібр вздовж дії зусилля розтягу.

В стіні резервуара зусиллю розтягу від зовнішнього навантаження $N_{E k}$ чинить опір переріз зі сталефібробетону $S_{c f, c r c}$ та опір поздовжньої арматури $S_{s, c r c}[5,6]$. Значення $S_{s, c r c}$ визначається за умови, що деформації в поздовжній арматурі перед утворенням тріщин рівні граничним деформаціям розтягу сталефібробетону, які визначаються за формулою $\varepsilon_{c f t u}=2 f_{c f t k} / E_{c k}[1]$ ( $E_{c k}-$ початковий модуль пружності бетону). 
Таблиця 2

Визначення характеристичного значення міцності сталефібробетону на осьовий розтяг $f_{c f t k}$

\begin{tabular}{|c|c|c|c|c|c|c|}
\hline \multicolumn{4}{|c|}{ Фактори варіювання } & \multicolumn{2}{|c|}{ Міцність, МПа } & \multirow[b]{2}{*}{$\mathrm{f}_{\mathrm{cftk}} / \mathrm{f}_{\mathrm{ctk}}$} \\
\hline Клас & $\mathrm{f}_{\mathrm{ck}}, \mathrm{M \Pi а}$ & $1_{\mathrm{f}}, \mathrm{MM}$ & $\mu_{\mathrm{fv}}$ & $\mathrm{f}_{\text {cftk }}$ & $\mathrm{f}_{\text {ctk }}$ & \\
\hline \multirow{9}{*}{$\mathrm{C} 25 / 30$} & 22 & 40 & 0,002 & 2,00 & 1,80 & 1,11 \\
\hline & 22 & 40 & 0,01 & 2,24 & 1,80 & 1,24 \\
\hline & 22 & 40 & 0,018 & 2,53 & 1,80 & 1,40 \\
\hline & 22 & 50 & 0,002 & 2,01 & 1,80 & 1,12 \\
\hline & 22 & 50 & 0,01 & 2,28 & 1,80 & 1,27 \\
\hline & 22 & 50 & 0,018 & 2,60 & 1,80 & 1,44 \\
\hline & 22 & 60 & 0,002 & 2,02 & 1,80 & 1,12 \\
\hline & 22 & 60 & 0,01 & 2,31 & 1,80 & 1,28 \\
\hline & 22 & 60 & 0,018 & 2,65 & 1,80 & 1,47 \\
\hline \multirow{9}{*}{$\mathrm{C} 30 / 35$} & 25,5 & 40 & 0,002 & 2,32 & 2,00 & 1,16 \\
\hline & 25,5 & 40 & 0,01 & 2,60 & 2,00 & 1,30 \\
\hline & 25,5 & 40 & 0,018 & 2,93 & 2,00 & 1,46 \\
\hline & 25,5 & 50 & 0,002 & 2,33 & 2,00 & 1,17 \\
\hline & 25,5 & 50 & 0,01 & 2,64 & 2,00 & 1,32 \\
\hline & 25,5 & 50 & 0,018 & 3,01 & 2,00 & 1,51 \\
\hline & 25,5 & 60 & 0,002 & 2,61 & 2,00 & 1,31 \\
\hline & 25,5 & 60 & 0,01 & 3,60 & 2,00 & 1,80 \\
\hline & 25,5 & 60 & 0,018 & 4,97 & 2,00 & 2,49 \\
\hline \multirow{9}{*}{$\mathrm{C} 32 / 40$} & 29 & 40 & 0,002 & 2,64 & 2,10 & 1,26 \\
\hline & 29 & 40 & 0,01 & 2,95 & 2,10 & 1,41 \\
\hline & 29 & 40 & 0,018 & 3,33 & 2,10 & 1,59 \\
\hline & 29 & 50 & 0,002 & 2,88 & 2,10 & 1,37 \\
\hline & 29 & 50 & 0,01 & 3,68 & 2,10 & 1,75 \\
\hline & 29 & 50 & 0,018 & 4,87 & 2,10 & 2,32 \\
\hline & 29 & 60 & 0,002 & 2,95 & 2,10 & 1,41 \\
\hline & 29 & 60 & 0,01 & 4,01 & 2,10 & 1,91 \\
\hline & 29 & 60 & 0,018 & 5,50 & 2,10 & 2,62 \\
\hline
\end{tabular}

Виходячи 3 наведених умов, зусилля $S_{c r c}$, яке може витримати розрахунковий переріз стіни резервуара перед утворенням тріщин, можна визначити за формулою

$$
S_{\text {cre }}=S_{\text {cf } f_{\text {cre }}}+S_{\text {gerc }}=b h f_{\text {cfth }}+\varepsilon_{\text {cftu }} E_{g} A_{g x}
$$

де $E_{s}$ - модуль пружності поздовжньої арматури. 
Для побудови математичних моделей міцності дисперсно армованого бетону $f_{c f t k}$ та зусилля опору перерізу тріщиноутворенню $S_{c r c}$ реалізований трифакторний трирівневий план Бокса-Бенкіна [7], в кожній точці якого визначалися вихідні параметри $f_{c f t k}$ і $S_{c r c}$, за формулами (2), (3) та (5) (табл. $3)$.

Таблиця 3

Матриця плану Бокса-Бенкіна та вихідні розрахункові параметри (у дужках наведені кодові значення необхідних факторів)

\begin{tabular}{|c|c|c|c|c|c|}
\hline \multirow{2}{*}{$\begin{array}{c}\text { Точки } \\
\text { плану }\end{array}$} & \multicolumn{3}{|c|}{ Матриця планування } & \multicolumn{2}{c|}{ Вихідні параметри } \\
\cline { 2 - 6 } & $\begin{array}{c}x_{1,} \\
f_{c r}, \text { МПа }\end{array}$ & $\begin{array}{c}x_{2,} \\
l_{f}, \text { мм }\end{array}$ & $\begin{array}{c}x_{3}, \\
\mu_{f v}, \%\end{array}$ & $\begin{array}{c}f_{c f t k}, \\
\text { МПа }\end{array}$ & $\begin{array}{c}S_{c r c}, \\
\text { кH }\end{array}$ \\
\hline 1 & $29(+1)$ & $60(+1)$ & $0,010(0)$ & 4,01 & 796,4 \\
\hline 2 & $29(+1)$ & $40(-1)$ & $0,010(0)$ & 2,95 & 585,9 \\
\hline 3 & $22(-1)$ & $60(+1)$ & $0,010(0)$ & 2,31 & 463,5 \\
\hline 4 & $22(-1)$ & $40(-1)$ & $0,010(0)$ & 2,24 & 449,4 \\
\hline 5 & $29(+1)$ & $50(0)$ & $0,018(+1)$ & 4,87 & 967,2 \\
\hline 6 & $29(+1)$ & $50(0)$ & $0,002(-1)$ & 2,88 & 572,0 \\
\hline 7 & $22(-1)$ & $50(0)$ & $0,018(+1)$ & 2,61 & 523,7 \\
\hline 8 & $22(-1)$ & $50(0)$ & $0,002(-1)$ & 2,01 & 403,3 \\
\hline 9 & $25,5(0)$ & $60(+1)$ & $0,018(+1)$ & 4,97 & 989,0 \\
\hline 10 & $25,5(0)$ & $60(+1)$ & $0,002(-1)$ & 2,61 & 519,3 \\
\hline 11 & $25,5(0)$ & $40(-1)$ & $0,018(+1)$ & 2,93 & 583,0 \\
\hline 12 & $25,5(0)$ & $40(-1)$ & $0,002(-1)$ & 2,32 & 461,6 \\
\hline 13 & $25,5(0)$ & $50(0)$ & $0,010(0)$ & 2,64 & 525,3 \\
\hline
\end{tabular}

Квадратичні рівняння регресії (математичні моделі) для описання вихідних параметрів $\bar{y}$ відповідно до плану експерименту мають такий загальний вигляд:

$$
\begin{gathered}
\bar{y}=b_{0}+b_{1} x_{1}+b_{2} x_{2}+b_{2} x_{a}+b_{11} x_{1}{ }^{2}+b_{22} x_{2}{ }^{2}+b_{23} x_{a}{ }^{2}+b_{12} x_{1} x_{2}+ \\
+b_{13} x_{1} x_{3}+b_{28} x_{1} x_{28}
\end{gathered}
$$

де $b_{0}, b_{i}, b_{i \mathrm{i}}, b_{\mathrm{ij}}$ - це коефіцієнти рівняння регресії. Вони для трирівневого плану Бокса-Бенкіна знаходяться статистичним шляхом за формулами [7].

Серед знайдених коефіцієнтів рівняння регресії за критерієм Стьюдента для рівняння для визначення міцності сталефібробетону на розтяг $f_{c f t k}$ не значущим виявився коефіцієнт $b_{33}$, а для визначення зусилля тріщиноутворення $S_{c r c}$ - коефіцієнт $b_{11}$. 3 урахуванням цього математичні моделі для теоретичних значень вихідних параметрів можуть бути записані у вигляді:

- для міцності сталефібробетону на розтяг

$$
\begin{gathered}
f_{\text {cft }} \text { teor }=2,66+0,91 x_{1}+0,42 x_{2}+0,94 x_{a}+0,36 x_{1}{ }^{2}+0,27 x_{2}{ }^{2}+ \\
+0,24 x_{1} x_{2}+0,37 x_{1} x_{3}+0,43 x_{2} x_{2} ;
\end{gathered}
$$


- для зусилля, що сприймається перерізом перед утворенням тріщин (зусилля тріщиноутворення),

$$
\begin{gathered}
S_{\text {ereteor }}=476,1+123_{s} 6 x_{1}+75,1 x_{2}+127,6 x_{a}+27,5 x_{2}{ }^{2}+70,4 x_{\mathrm{a}}{ }^{2}+ \\
+43,7 x_{1} x_{2}+65,8 x_{1} x_{a}+76,9 x_{2} x_{2} .
\end{gathered}
$$

Середне відношення теоретичних значень міцності сталефібробетону розтягу, визначених за формулою (7), до значень вихідних параметрів (табл. 3) склало $f_{c t r, t e o r} / f_{c f t r}=0,97$ при коефіцієнті мінливості 0,15 , середнє відношення значень зусилля тріщиноутворення, визначених за формулою (8), до значень вихідних параметрів (табл. 3) $-S_{c r c, t e o r} / S_{c r c}=0,98$ при коефіцієнті мінливості 0,06. Наведені статистики свідчать, що формули (7) i (8) адекватно описують вихідні параметри числового експерименту (табл. 3) і можуть бути використані для аналізу впливу факторів варіювання на тріщиностійкість стіни резервуара та визначення їхніх оптимальних значень.

Аналіз впливу основних факторів на зусилля опору утворенню тріщин в стіні резервуара. 3 аналізу рівняння регресії (8) видно, що найбільший вплив на зусилля тріщиноутворення в розрахунковому перерізі стіни резервуара мають міцність бетонної матриці та коефіцієнт об'ємного іiі дисперсного армування. Про це свідчать значення коефіцієнтів рівняння регресії, які при факторі міцності $x_{1}$ рівний $b_{1}=$ 123,6 , а при третьому факторі $x_{3}-b_{3}=127,6$. Значення коефіцієнта при факторі $x_{2}$, а також при факторах в квадраті і факторах їхньої взаємодії суттєво менші. Так наприклад, за довжини фібри $l_{f}=50$ мм і коефіцієнта об'ємного дисперсного армування $\mu_{f v}=0,01$ при класі бетонної матриці C25/30 величина зусилля тріщиноутворення в розрахунковому перерізі стіни резервуара складає $S_{c r c}=352,5$ кН, а при класах С $30 / 35$ і С $32 / 40$ відповідно $S_{c r c}=476,1$ і 599,7 кН (на 30,2 і 92,0\% більше) (рис. 1).

Для бетону класу С30/35 при довжині фібри 50 мм застосування дисперсного армування з відсотком $0,6 \%$ дає можливість досягти зусилля тріщиноутворення в стіні резервуара рівного $S_{c r c}=429,9$ кН. Якщо збільшити відсоток об'ємного армування до $\mu_{f v}=1,0$ i $1,8 \%$ опір тріщиноутворенню збільшується до $S_{c r c}=476,1$ і 674,1 кН. 3 наведених видно, що опір тріщиноутворенню зростає не пропорційно збільшенню відсотка об'ємного дисперсного армування. Так для бетону класу С30/35 збільшення $\mu_{f v}$ в три рази підвищує зусилля тріщиноутворення в 1,57 рази. Залежність $S_{c r c}$ від $\mu_{f v}$ має криволінійний характер (рис. 1).

Взагалі, якщо прийняти матрицю 3 дрібнозернистого бетону класу C32/40 і дисперсно армувати іï фіброю довжиною $l_{f}=60$ мм з об'ємним коефіцієнтом $\mu_{f v}=0,018$, то зусилля тріщиноутворення в розрахунковому перерізі стіни резервуара може досягнути значення $S_{c r c}=1086,7 \mathrm{\kappa H}$, що в 2,9 рази більше, якщо б не використовувалося дисперсне армування (без дисперсного армування $\left.S_{c, c r c}=375,1 \kappa \mathrm{H}\right)$. 

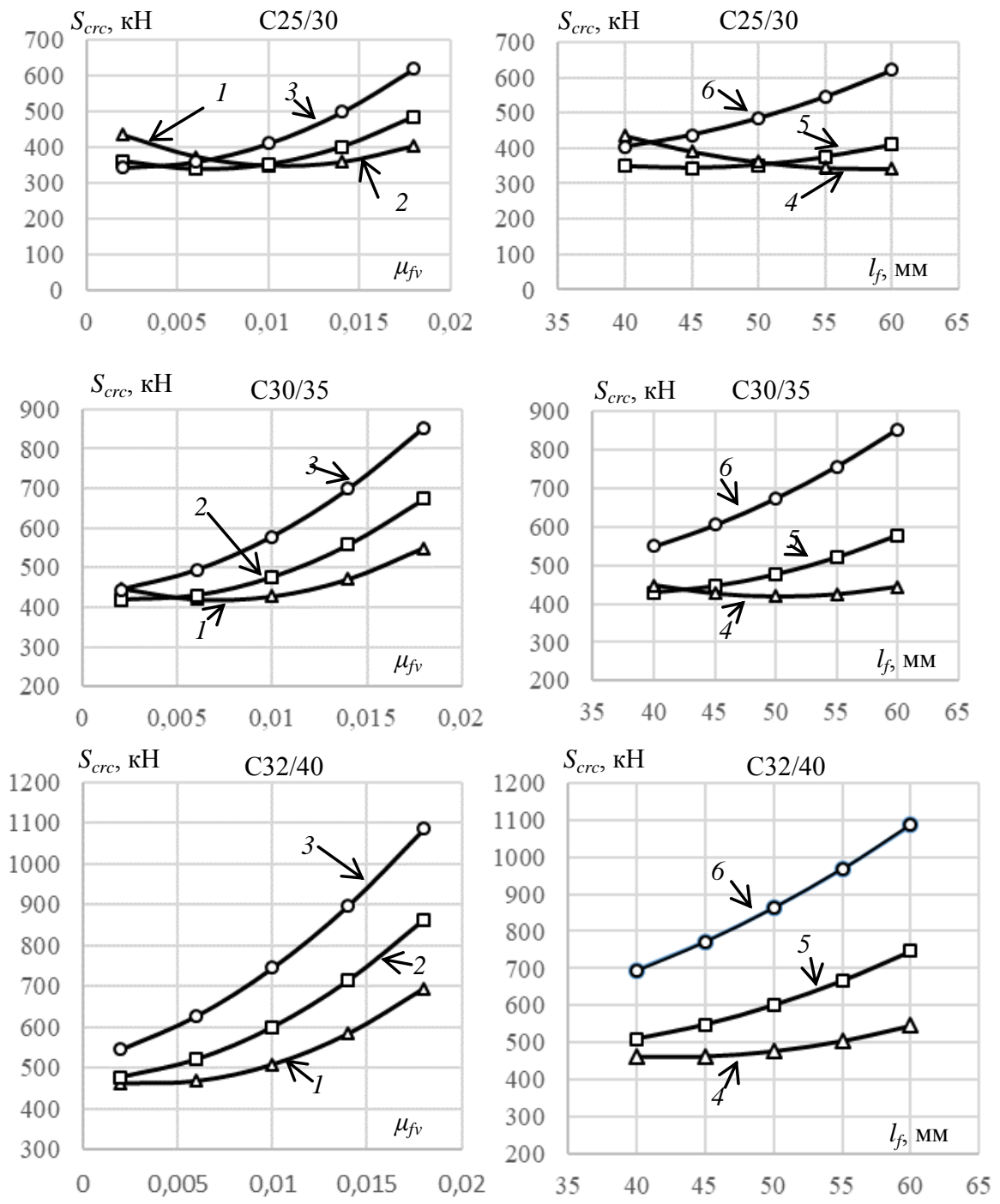

Рис. 1. Залежність зусилля тріщиноутворення в стіні резервуара $S_{c r c}$ від класу бетону С, коефіцієнта об'ємного дисперсного армування $\mu_{f v}$ та довжини фібр: 1, 2, 3 - відповідно $l_{f}=40 ; 50 ; 60$ мм; 4, 5, 6 - відповідно $\mu_{f v}=0,002 ; 0,010 ; 0,018$ 
Визначення раціональних параметрів дисперсного армування стіни резервуара. В нижньому розрахунковому перерізі стіни резервуара від дії зовнішнього характеристичного навантаження виникає центрально розтягувальне зусилля $S_{E k}=480$ кН та граничне розрахункове зусилля $S_{E d}=$ 510 кН. За значенням $S_{E d}$ розрахунком за граничними станами першої групи визначена кільцева робоча арматура (10Ø12А500С на 1 м висоти стіни).

Як правило, перевірку тріщиностійкості виконують розрахунком за граничними станами другої групу на зусилля від дії

характеристичних навантажень. Якщо так підібрати параметри дисперсного армування таким чином, щоб межею утворення тріщин було зусилля $S_{E k}$, але відносно резервуара, в якому виникнення тріщин в стіні не допускається, при цьому зусиллі експлуатація резервуара не можлива, а робоча арматура буде не повістю використовуватися в роботі.

3 огляду на наведене в центрально розтягнутих комбіновано армованих елементах доцільно за граничний стан вичерпання несучої здатності прийняти одночасне досягнення в робочій арматурі розрахункових значень напружень та утворення тріщин в дисперсно армованому бетоні, тобто умовами настання граничного стану комбіновано армованої стіни можна вважати $S_{U L S} \geq S_{E d}$ та $S_{S L S} \geq S_{E d}$, де $S_{U L S}-$ несуча здатність перерізу, яка забезпечується кільцевою робочою арматурою; $S_{S L S}$ - зусилля, яке сприймає комбіновано армований бетонний переріз перед утворенням тріщин.

3 наведених умов в прикладі стіни циліндричного резервуару перша 3 них забезпечена розрахунком необхідної в перерізі робочої стержньової арматури, а для забезпечення другої умови необхідно визначити оптимальних параметрів дисперсного армування бетону. Задача вирішується шляхом аналізу зусиль тріщиноутворення в стіні на основі отриманої математичної моделі (8), прийнявши $S_{S L S}=S_{c r c, t e o r}$.

Аналіз визначених за формулою (8) значень $S_{S L S}$ засвідчує, що при використані бетону класу С25/30 необхідного опору стіни тріщиноутворенню можливо досягти тільки при застосуванні фібри довжиною $l_{f}=60$ мм 3 об'ємним армуванням $\mu_{f v}=1,44 \%$ (табл. 4). При використанні бетону класу бетону С $30 / 35$ можливе використання всієї номенклатури хвилеподібної фібри з об'ємним дисперсним армуванням, вказаним в табл. 4 (усі значення $\mu_{f v}$ знаходяться в межах рекомендованих ТУ У В.2.7-28.7-00191046-015:2007). Що стосується більш міцного бетону класу С $32 / 40$, то для його дисперсного армування доцільно використовувати фібру довжиною 40 і 50 мм, а при використанні фібри довжиною 60 мм при самому мінімальному відсотку об'ємного армування стіни буде необгрунтовано високий запас опору тріщиностійкості. 
Таблиця 4

Рекомендовані параметри дисперсного армування стіни резервуара

\begin{tabular}{|c|c|c|c|c|}
\hline $\begin{array}{c}\text { Клас } \\
\text { бетону }\end{array}$ & $\begin{array}{c}\text { Довжина } \\
\text { фібри, } \\
\text { lf, мм }\end{array}$ & $\begin{array}{c}\text { Відсоток } \\
\text { ррмування, } \\
\mu \mathrm{fv}, \%\end{array}$ & $\begin{array}{c}\text { Зусилля } \\
\text { тріщиноутво- } \\
\text { рення, SSLS, кH }\end{array}$ & $\begin{array}{c}\text { Витрати } \\
\text { фібри, } \\
\text { кг/м3 }\end{array}$ \\
\hline $\mathrm{C} 25 / 30$ & 60 & 1,44 & 509,0 & 113,04 \\
\hline $\mathrm{C} 30 / 35$ & 40 & 1,64 & 514,1 & 128,74 \\
\hline $\mathrm{C} 30 / 35$ & 50 & 1,20 & 512,4 & 94,2 \\
\hline $\mathrm{C} 30 / 35$ & 60 & 0,70 & 511,2 & 54,95 \\
\hline $\mathrm{C} 32 / 40$ & 40 & 1,10 & 516,6 & 86,35 \\
\hline $\mathrm{C} 32 / 40$ & 50 & 0,50 & 510,3 & 39,25 \\
\hline
\end{tabular}

За даними табл. 4, враховуючи витрати фібри на 1 метр кубічний бетону, раціональними параметрами його об'ємного дисперсного армування є: при використанні бетону класу C30/35 довжина фібри 60 мм 3 витратами іiі 50 кг на один кубічний метр бетону; при використанні класу бетону C32/40 довжина фібри 50 мм з витратами 39 кг на один кубічний метр бетону. Кінцевий вибір параметрів дисперсного армування із наведених двох необхідно визначати за вартістю, виходячи з реальних умов зведення резервуару.

Висновки. 1. Дослідженнями доведено доцільність при зведенні циліндричних резервуарів, в яких не допускається утворення тріщин в процесі експлуатації, використовувати комбіноване армування стін, уникаючи застосування попереднього напружування кільцевої арматури, яке пов'язане з суттєвими енергетичними затратами.

2. Для встановлення раціональних параметрів об'ємного дисперсного армування бетону для зведення циліндричного резервуара доцільно використовувати математичні моделі для визначення міцності сталефібробетону на розтяг та зусилля тріщиноутворення, залежно від основних факторів впливу: міцність бетону, довжина фібри та коефіцієнт об'ємного дисперсного армування.

3. Розроблена методика побудови математичних моделей на підставі виконання математично планованого експерименту для комбіновано армованої стіни резервуара для рідини може бути використана для визначення раціональних параметрів дисперсного армування і для інших центрально розтягнутих залізобетонних елементів.

\section{References}

1. DBN V.2.6-98:2009. Betonni ta zalizobetonni konstruktsiyi. Osnovni polozhennya. - Kyiv: Minrehionbud Ukrayiny, 2011. $-71 \mathrm{~s}$.

2. Babych Ye. M. Pidvyshchennya pokaznykiv ekspluatatsiynoyi prydatnosti z'hynal'nykh zalizobetonnykh elementiv shlyakhom vykorystannya chastkovoho dyspersnoho armuvannya / Ye. M. Babych, Andriichuk O. V., I. V. Shvets // IV 
Mizhnarodna naukovo-praktychna internet-konferentsiya molodykh uchenykh ta studentiv «Innovatsiyi u budivnytstvi», Lutsk, Lutsk NTU, 14 may 2019, - s. 14-17.

3. Babych V. Ye. Vplyv dyspersnoho armuvannya roztyahnutoyi zony zalizobetonnykh balok na yikhnyu trishchynostiykist' / V. Ye. Babych, O. Ye. Polianovska, I. V. Shvets // Resursoekonomni materialy, konstruktsii, budivli ta sporudy. 2019. Vyp. 37. S. 118-128.

4. Babych Ye. M. Zalizobetonni balky z pidvyshchenoyu trishchyno-stiykistyu / Ye. M. Babych , V.Ye. Babych, I. V. Shvets // Ekspluatatsiya ta rekonstruktsiya budivel i sporud: Tezy dopovidey III mizhnarodnoyi konferentsiyi. - Odesa: ODABA, 2019.- 23 s.

5. Babych Ye. M. Metod vyznachennya optymal'nykh parametriv dyspersnoho armuvannya tsentral'no roztyahnutykh zalizobetonnykh elementiv / Ye. M Babych, V.Ye. Babych, O. Ye. Polianovska, I. V. Svets // Materialy III Mizhnarodnoyi azerbaydzhansko-ukrayinskoyi naukovo-praktychnoyi konferentsiyi «BUILDING INNOVATIONS - 2020», 1-2 june 2020, Poltava, NU "Poltavs'ka politekhnika imeni Yuriya Kondratyuka" - S. 54-56.

6. DSTU-N B V.2.6-218:2016. Nastanova z proektuvannya ta vyhotovlennya konstruktsiy z dyspersnoarmovanoho betonu. - Kyiv: DP «UkrNDNTS», 2017. - 49 s.

7. Dvorkin L.J. Rozvyazannya budivelno-tekhnolohichnykh zadach metodamy matematychnoho planuvannya eksperymentu / L.J. Dvorkin, O.L. Dvorkin, V.V. Zhytkovskyy - Rivne: NUWM, 2011. - 174 s.

\section{Список використаної літератури}

1. ДБН В.2.6-98:2009. Бетонні та залізобетонні конструкції. Основні положення. - Київ: Мінрегіонбуд України, 2011. - 71 с.

2. Бабич Є.M. Підвищення показників експлуатаційної придатності згинальних залізобетонних елементів шляхом використання часткового дисперсного армування / С.М. Бабич, О. В. Андрійчук, I. В. Швець // IV міжнародна науково-практична інтернет-конференція молодих учених та студентів «Інновації у будівництві», м. Луцьк, Луцький НТУ, 14 травня 2019 року, -c. 14 - 17.

3. Бабич В. Є. Вплив дисперсного армування розтягнутої зони залізобетонних балок на їхню тріщиностійкість / В. Є. Бабич, О. Є. Поляновська, I. В. Швець // Ресурсоекономні матеріали, конструкції, будівлі та споруди: збірник наук. праць - Рівне: НУВГП, 2019. - Випуск 37, - С. 118-128.

4. Бабич Є. М. Залізобетонні балки з підвищеною тріщиностійкістю/ Є. М. Бабич, В. С. Бабич, I. В. Швець // Експлуатація та реконструкція будівель і споруд: тези доповідей ІІІ міжнародної конференції. - Одеса: ОДАБА, 2019.- С. 23.

5. Бабич Є. М. Метод визначення оптимальних параметрів дисперсного армування центрально розтягнутих залізобетонних елементів. / С. М. Бабич, В. С. Бабич, О. Є. Поляновська, I. В. Швець // Матеріали III Міжнародної азербайджансько-української науково-практичної конференції «BUILDING INNOVATIONS - 2020», 1 - 2 червня 2020 р., м. Полтава, НУ "Полтавська політехніка імені Юрія Кондратюка" - С. 54-56.

6. ДСТУ-Н Б В.2.6-218:2016. Настанова 3 проектування та виготовлення конструкцій з дисперсноармованого бетону. - Київ: ДП «УкрНДНЦ», 2017. - 49 с.

7. Дворкін Л.Й. Розв'язання будівельно-технологічних задач методами математичного планування експерименту / Л.Й. Дворкін, О.Л. Дворкін, В.В. Житковський. - Рівне: НУВГП, 2011. - 174 с. 